\title{
Hepatitis B Knowledge, Attitude and Vaccination Status among Nurses of Tamale Central Hospital, Ghana
}

\begin{abstract}
Abdul Rauf Alhassan
Department of Surgery, Tamale Teaching Hospital. P.O. Box TL 16; Tamale-Ghana.

*Corresponding Author: Abdul Rauf Alhassan, Department of Surgery, Tamale Teaching Hospital. P.O. Box TL 16; Tamale-Ghana.

Received date: April 07, 2021; Accepted date: April 28, 2021; Published date: May 07, 2021

Citation: Abdul Rauf Alhassan. (2021) Hepatitis B Knowledge, Attitude and Vaccination Status among Nurses of Tamale Central Hospital, Ghana. Clinical Research and Clinical Trials. 3(3); DOI:10.31579/2693-4779/035

Copyright: ( 2021 Abdul Rauf Alhassan. This is an open access article distributed under the Creative Commons Attribution License, which permits unrestricted use, distribution, and reproduction in any medium, provided the original work is properly cited.
\end{abstract}

\begin{abstract}
Background: In our healthcare setting transmission of hepatitis B is a big challenge to handle for both patients and healthcare providers especially those in frequent contact with blood. Objectives: To determine Hepatitis B knowledge, attitude, and vaccination status among nurses of Tamale Central Hospital.

Methods: This study was conducted using a descriptive cross-sectional survey. Data analysis was done with SPSS version 20. Bivariate analysis was done using chi-square to determine the relationships.

Results: The study recorded a response rate of $92.5 \%$. Majority (59.6\%) had high, $36.4 \%$ had moderate and $4.0 \%$ had low knowledge hepatitis B. Hepatitis knowledge level was associated with: age $X^{2}(4)=17.789, P=0.001$, sex, $X^{2}(2)=13.203, \mathrm{P}=0.001$, educational level, $X^{2}(6)=17.552, \mathrm{P}=0.007$, nursing category, $X^{2}(4)=19.226, \mathrm{P}=0.001$, and duration of nursing practice $X^{2}(2)=19.492, \mathrm{P} \leq 0.001$. About $42.9 \%$ had positive attitude toward hepatitis $\mathrm{B}$ prevention and attitude level towards hepatitis B was associated with: marital status $X^{2}(1)=11.090, \mathrm{P}=0.001$, residential address $X^{2}(2)=11.411, \mathrm{P}=0.003$ and duration of nursing practice $X^{2}(1)=4.769, \mathrm{P}=0.029$. About $84.8 \%$ of nurses started vaccination against hepatitis B and $77.3 \%$ completed at least three doses of the vaccination. The only factor with a statistically significant relationship with vaccination completeness status was respondent marital status $X^{2}(1)=8.063, P=0.005$.
\end{abstract}

Conclusion: Nurses' knowledge of hepatitis B was very good. And more than half of the nurses had a negative attitude towards hepatitis B prevention. In terms of vaccination more than three-fourth of them started and completed three doses of hepatitis B vaccination.

Keywords: attitude; hepatitis b; knowledge; vaccination; tamale; ghana

\section{Introduction}

Chronic hepatitis B infection has over the years increased the cases of liver cirrhosis and hepatocellular carcinoma. According to the World Health Organization 2017 report on hepatitis B, there are close to 257 million people who are infected with chronic hepatitis B globally [1]. Low-income countries are overburden with hepatitis B infection accompanied by its progression to the problems of liver cirrhosis and hepatocellular carcinoma [2].

Many epidemiological studies have indicated varying states of hepatitis B endemicity globally and areas with higher endemicity are located in SubSaharan Africa and East Asia where the adult population of 5 and 10\% are chronically infected as compared to areas in western and North America where less than $1 \%$ of the population is chronically infected [3]. In sub-Saharan Africa, hepatitis B is an endemic problem, it accounts for 87890 deaths every year, and $80 \%$ of all cases of hepatocellular carcinoma recorded.[4] In Ghana, the prevalence of chronic hepatitis B virus infection is high ( $\geq 8 \%$ ) among the general population, and $11 \%$ among pregnant women and in blood donors, and Northern Region is $13.1 \%$ [5].
In our healthcare setting transmission of hepatitis B is a big challenge to handle for both patients and healthcare providers especially those in frequent contact with blood. And factors implicated in this situation include knowledge, attitude, and practice of prevention of infection including vaccination. In India, a study among medical students showed that knowledge and attitude of medical students were good towards hepatitis B vaccination but their practice was not sufficient as less than $33 \%$ of the students were not unvaccinated [6]. In another similar study in Bangladesh among nurses indicated adequate knowledge of hepatitis vaccination among $67.3 \%$ of the respondents but less $(49.3 \%$ ) good hepatitis vaccination practice [7].

Somewhere in Africa, a study in Ethiopia indicated more than $80.0 \%$ of respondents had an adequate knowledge positive attitude towards hepatitis B prevention but only 5 (2.0\%) of students had completed the three doses schedule of hepatitis B vaccination [8]. In another study in Ghana revealed a prevalence of hepatitis B vaccination uptake to be $53.4 \%$ among healthcare workers [9]. 
A study by Ibrahim on the prevalence of hepatitis $b$ virus infection among health care workers in Tamale revealed the prevalence of hepatitis B to be $26.3 \%$ among the healthcare workers and this was higher as compared to the prevalence of $14.5 \%$ for the comparison group (non-healthcare workers) in the study [10]. This is not good considering the current means of dealing with this occupational hazard is effective immunization of all healthcare provides that includes nurses with available vaccines which is efficient and safe, hence this study on nurses was to ascertain their knowledge, attitude, and practice (vaccination) of hepatitis B vaccination since they form one of the central healthcare workers who are at greater risk of contracting the hepatitis B virus and are also an important stakeholder in public education on prevention of hepatitis B.

\section{Method and materials}

A descriptive Cross-sectional survey was adopted be for this study among nurses of Tamale Central Hospital $(\mathrm{TCH})$. Health care providers especially nurses in developing nations are at severe risk for infection from blood-borne pathogens particularly hepatitis $B$ virus $(H B V)-$ because of the high prevalence in these regions.

\section{Sample Size Determination}

The sample size was calculated using the Yamane formula for calculating sample size which is stated below; where $\mathrm{n}$ is the sample size, $\mathrm{N}$ is the population size, and $\mathrm{e}$ is the level of precision. $\mathrm{N}=415$, $\mathrm{e}=0.05$.

$$
n=\frac{N}{1+N(e)^{2}} n=\frac{415}{1+415(0.05)^{2}}=204
$$

The total sample size will be 204 plus 5\% (10) for non-response, hence 214. Stratified and simple random sampling techniques were used for selecting study participants, $(\mathrm{RGN}=73, \mathrm{RM}=44$, and $\mathrm{EN}=97)$.

\section{Data collection tool and procedure}

A self-administrable structured questionnaire was used to collect data from the study group. The questionnaire was a design taken guide CDC, $\mathrm{WHO}$, and MOH Ghana guidelines on the prevention of hepatitis in the healthcare setting. Questions were divided into four sections: demography, knowledge on hepatitis B, attitude toward hepatitis B prevention, and practice of hepatitis vaccination.

The study questionnaire was piloted to identify areas that needed to be corrected to make the necessary changes before going to the study area for the data collection. Thus; corrections were made before administering the questionnaire in the study area. Final data collection was done by the researcher and assistance from two trained research assistants from the duration of $14^{\text {th }}$ February 2020 to $13^{\text {th }}$ July 2020 .

\section{Method of data analysis}

Data entry and analysis was done using SPSS version 20 (IBM Corp., 2011 and NY). Responses to categorical variables were coded to allow for quantitative analysis. Data cleaning was done to ensure data accurateness and to maintain the good validity of the study. The continuous variable like age was presented as means with standard deviation. Categorical variables like vaccination status were presented as proportion. Graphs and tables were used to present the study data. Bivariate analysis for the association was done using Chi-square.

Respondents' responses to questions on knowledge and attitude of hepatitis B were scored. Individual total scores were transformed into percentages for classification into knowledge and attitude levels. Those with a score of $60.0 \%$ and above were classified to have a Positive attitude level and those with scores below $60.0 \%$ were classified as negative attitude level. For knowledge score below $60 \%$ was for poor, $60 \%-79 \%$ for moderate, and $80 \%$ and above for high knowledge level on hepatitis B.

\section{Inclusion and exclusion criteria}

All nurses working in Tamale Central Hospital were in the inclusion criteria. And those in the exclusion criteria were nurses who were not randomly selected, those who denied consent to participate in this study, and all those who have worked less than one month in the hospital.

\section{Quality Control}

Data collected in the field was double-checked to guarantee that, all the information required was captured and recorded. In circumstances where a questionnaire was not correctly filled, it had to be re-administered on the respondent by tracing the participant through his or her phone number. Data security was maintained by entering the data on a personal computer with a password. To ensure the quality of data entered, another person was made to separately recheck each entry.

\section{Ethical consideration}

Respondents' consent was gained to answer the questionnaire, the information provided was treated with confidentiality. Any form of physical or psychological harm towards respondents' was avoided. All sources for information used in this research were duly acknowledged to avoid any form of plagiarism.

\section{Results}

\section{Demographic characteristics}

The survey questionnaires that were sent out about 198 out of 214 questionnaires were successfully filled and returned. The mean age of the respondents was $30.6 \pm 4.6$ years, with minimum and maximum ages of 18 and 57 years respectively. The modal age was 30.0 years. About $72.2 \%$ of the respondents were married, with the majority $(82.8 \%)$ of the respondent resides in urban areas. About $43.9 \%$ of the respondents have enrolled nurses (EN), 35.4\% were registered general nurses (RGN) and $20.7 \%$ were registered midwives (RM). With years of work experience, most $(63.1 \%)$ of them had worked for 6 years and above (Table: 1).

\begin{tabular}{|c|c|c|c|}
\hline & & Frequency $(\mathrm{n}=198)$ & Percentage \\
\hline \multirow{3}{*}{ Age group } & 29 years and below & 65 & $32.8 \%$ \\
\hline & $30-39$ years & 125 & $63.1 \%$ \\
\hline & 40 years and above & 8 & $4.0 \%$ \\
\hline \multirow{2}{*}{ Sex } & Male & 97 & $49.0 \%$ \\
\hline & Female & 101 & $51.0 \%$ \\
\hline \multirow{2}{*}{ Religion } & Islam & 148 & $74.7 \%$ \\
\hline & Christianity & 50 & $25.3 \%$ \\
\hline
\end{tabular}




\begin{tabular}{|l|l|l|l|}
\hline \multirow{4}{*}{ Marital Status } & Married & 143 & $72.2 \%$ \\
\cline { 2 - 4 } & Single & 55 & $27.8 \%$ \\
\hline \multirow{5}{*}{ Residence address } & Urban & 164 & $82.8 \%$ \\
\cline { 2 - 4 } & Peri-Urban & 7 & $3.5 \%$ \\
\cline { 2 - 4 } & Rural & 27 & $13.6 \%$ \\
\hline \multirow{5}{*}{ Highest educational level } & Basic certificate & 70 & $35.4 \%$ \\
\cline { 2 - 4 } & Diploma & 71 & $35.9 \%$ \\
\cline { 2 - 4 } & Post diploma & 17 & $8.6 \%$ \\
\cline { 2 - 4 } & Degree & 40 & $20.2 \%$ \\
\hline \multirow{3}{*}{ Nursing category } & Registered general nurse & 70 & $35.4 \%$ \\
\hline & Registered midwife & 41 & $20.7 \%$ \\
\cline { 2 - 4 } & Enrolled nurse & 87 & $43.9 \%$ \\
\hline & 5 years and less & 73 & $36.9 \%$ \\
\hline & 6 years and more & 125 & $63.1 \%$ \\
\hline
\end{tabular}

Source: field survey, 2020.

\section{Table 1: Demographic characteristics of respondents}

\section{Respondents' knowledge of hepatitis B}

The majority (92.4\%) of the respondents knew that hepatitis B is caused by a virus and only a few of the respondents indicated that hepatitis B can be caused by bacteria $(5.6 \%)$ and fungi $(5.1 \%)$. On the transmission of hepatitis $\mathrm{B}$, most of the respondents indicated that it can be transmitted through: sexual intercourse $(79.8 \%)$, blood transfusion $(93.9 \%)$, and childbirth (83.8\%) (Table: 2 ).

\begin{tabular}{|c|c|c|c|}
\hline & & Frequency $(\mathrm{n}=198)$ & Percentage \\
\hline \multicolumn{4}{|l|}{ Causes of Hepatitis B infection } \\
\hline \multirow{2}{*}{ Bacteria is a cause of Hepatitis B infection } & Yes & 11 & $5.6 \%$ \\
\hline & No & 187 & $94.4 \%$ \\
\hline \multirow{3}{*}{ The virus is the cause of Hepatitis B infection } & Yes & 183 & $92.4 \%$ \\
\hline & No & 10 & $5.1 \%$ \\
\hline & Don't know & 5 & $2.5 \%$ \\
\hline \multirow{3}{*}{ Fungi is the cause of Hepatitis B infection } & Yes & 1 & $0.5 \%$ \\
\hline & No & 188 & $94.9 \%$ \\
\hline & Don't know & 9 & $4.5 \%$ \\
\hline \multicolumn{4}{|l|}{ Transmission routes } \\
\hline \multirow{3}{*}{ Sexual intercourse is a transmission route for $\mathrm{HBV}$} & Yes & 158 & $79.8 \%$ \\
\hline & No & 39 & $19.7 \%$ \\
\hline & Don't know & 1 & $0.5 \%$ \\
\hline \multirow{3}{*}{ Blood transfusion is a transmission route for $\mathrm{HBV}$} & Yes & 186 & $93.9 \%$ \\
\hline & No & 10 & $5.1 \%$ \\
\hline & Don't know & 2 & $1.0 \%$ \\
\hline \multirow{3}{*}{ Air is a transmission route of $\mathrm{HBV}$} & Yes & 16 & $8.1 \%$ \\
\hline & No & 173 & $87.4 \%$ \\
\hline & Don't know & 9 & $4.5 \%$ \\
\hline
\end{tabular}




\begin{tabular}{|c|c|c|c|}
\hline \multirow{3}{*}{ Faeco-oral is a transmission route of $\mathrm{HBV}$} & Yes & 55 & $27.8 \%$ \\
\hline & No & 131 & $66.2 \%$ \\
\hline & Don't know & 12 & $6.1 \%$ \\
\hline \multirow{3}{*}{ Childbirth is a transmission route of $\mathrm{HBV}$} & Yes & 166 & $83.8 \%$ \\
\hline & No & 31 & $15.7 \%$ \\
\hline & Don't know & 1 & $0.5 \%$ \\
\hline \multirow{3}{*}{ Holding hands is a transmission route of $\mathrm{HBV}$} & Yes & 31 & $15.7 \%$ \\
\hline & No & 148 & $74.7 \%$ \\
\hline & Don't know & 19 & $9.6 \%$ \\
\hline
\end{tabular}

Source: field survey, 2020

\section{Table 2: Respondents knowledge of hepatitis B}

The majority of the respondents indicated that hepatitis B does not affect the following organs: stomach $(77.3 \%)$, lungs $(85.4 \%)$, skin $(75.8 \%)$, spleen $(55.1 \%)$, and intestines $(78.7 \%)$. On prevention majority (99.0\%) indicated that hepatitis $\mathrm{B}$ is preventable by vaccination and just about
$56.1 \%$ knew that there was post-prophylaxis medication for hepatitis B. Also, $91.9 \%$ knew that hepatitis B is preventable by Standard precaution practices (Table: 3 ).

\begin{tabular}{|c|c|c|c|}
\hline Type of organ affected & & Frequency $(\mathrm{n}=198)$ & Percentage \\
\hline \multirow{3}{*}{ HBV affects the stomach } & Yes & 36 & $18.2 \%$ \\
\hline & No & 153 & $77.3 \%$ \\
\hline & Don't know & 9 & $4.5 \%$ \\
\hline \multirow{3}{*}{$\mathrm{HBV}$ affects the lungs } & Yes & 26 & $13.1 \%$ \\
\hline & No & 169 & $85.4 \%$ \\
\hline & Don't know & 3 & $1.5 \%$ \\
\hline \multirow{2}{*}{ HBV affects the liver } & Yes & 197 & $99.5 \%$ \\
\hline & No & 1 & $0.5 \%$ \\
\hline \multirow{3}{*}{ HBV affects the skin } & Yes & 39 & $19.7 \%$ \\
\hline & No & 150 & $75.8 \%$ \\
\hline & Don't know & 9 & $4.5 \%$ \\
\hline \multirow{3}{*}{ HBV affects the spleen } & Yes & 68 & $34.3 \%$ \\
\hline & No & 109 & $55.1 \%$ \\
\hline & Don't know & 21 & $10.6 \%$ \\
\hline \multirow{3}{*}{ HBV affects the intestines } & Yes & 29 & $14.7 \%$ \\
\hline & No & 155 & $78.7 \%$ \\
\hline & Don't know & 13 & $6.6 \%$ \\
\hline \multicolumn{4}{|l|}{ Prevention of infection } \\
\hline \multirow[b]{2}{*}{ Hepatitis B is preventable with vaccination } & Yes & 196 & $99.0 \%$ \\
\hline & No & 2 & $1.0 \%$ \\
\hline \multirow{2}{*}{ Hepatitis B has post-exposure prophylaxis } & Yes & 111 & $56.1 \%$ \\
\hline & No & 37 & $18.7 \%$ \\
\hline
\end{tabular}




\begin{tabular}{|l|l|l|l|}
\cline { 2 - 4 } & Don't know & 50 & $25.3 \%$ \\
\hline $\begin{array}{l}\text { Hepatitis B is preventable by Standard precaution } \\
\text { practices }\end{array}$ & Yes & 182 & $91.9 \%$ \\
\cline { 2 - 4 } & No & 10 & $5.1 \%$ \\
\cline { 2 - 4 } & Don't know & 6 & $3.0 \%$ \\
\hline
\end{tabular}

Source: field survey, 2020

\section{Table 3: Respondents knowledge of hepatitis B}

\section{Respondents' hepatitis B knowledge level}

Majority (59.6\%) of the respondents had high knowledge on hepatitis B, $36.4 \%$ had moderate knowledge and $4.0 \%$ had low knowledge hepatitis B. Chi-square analysis showed statistically significant relation between hepatitis knowledge level and the following factor: age $X^{2}(4,198)=$
$17.789, \mathrm{P}=0.001, \operatorname{sex}, X^{2}(2,198)=13.203, \mathrm{P}=0.001$, educational level, $X^{2}(6,198)=17.552, \mathrm{P}=0.007$, nursing category, $X^{2}(4,198)=19.226, \mathrm{P}$ $=0.001$ and duration of nursing practice $X^{2}(2,198)=19.492, \mathrm{P} \leq 0.001$. However, the remaining factors were not statistically significant $(\mathrm{P}>$ 0.05) (Table 4).

\begin{tabular}{|c|c|c|c|c|c|c|c|}
\hline & & \multicolumn{2}{|c|}{ Hepatitis B knowledge level } & \multirow[b]{2}{*}{ Low } & \multirow[b]{2}{*}{$X^{2}$} & \multirow[b]{2}{*}{$\mathrm{df}$} & \multirow[b]{2}{*}{ P-value } \\
\hline & & High & Moderate & & & & \\
\hline \multirow{3}{*}{ Age group } & 29 years and below & 34 & 23 & 8 & 17.786 & 4 & .001 \\
\hline & $30-39$ years & 78 & 47 & 0 & & & \\
\hline & 40 years and above & 6 & 2 & 0 & & & \\
\hline \multirow{2}{*}{ Sex } & Male & 69 & 23 & 5 & 13.203 & 2 & .001 \\
\hline & Female & 49 & 49 & 3 & & & \\
\hline \multirow{2}{*}{ Religion } & Islam & 91 & 52 & 5 & 1.23 & 2 & .541 \\
\hline & Christianity & 27 & 20 & 3 & & & \\
\hline \multirow{2}{*}{ Marital Status } & Married & 79 & 59 & 5 & 5.405 & 2 & .067 \\
\hline & Single & 39 & 13 & 3 & & & \\
\hline \multirow{3}{*}{ Residence address } & Urban & 96 & 60 & 8 & 2.075 & 4 & .722 \\
\hline & Peri-Urban & 4 & 3 & 0 & & & \\
\hline & Rural & 18 & 9 & 0 & & & \\
\hline \multirow{4}{*}{ Highest educational level } & Basic certificate & 40 & 25 & 5 & 17.552 & 6 & .007 \\
\hline & Diploma & 33 & 35 & 3 & & & \\
\hline & Post diploma & 15 & 2 & 0 & & & \\
\hline & Degree & 30 & 10 & 0 & & & \\
\hline \multirow{3}{*}{ Nursing category } & Registered general nurse & 49 & 19 & 2 & 19.225 & 4 & .001 \\
\hline & Registered midwife & 15 & 26 & 0 & & & \\
\hline & Enrolled nurse & 54 & 27 & 6 & & & \\
\hline \multirow{2}{*}{ Duration of nursing practice } & 5 years and less & 33 & 32 & 8 & 19.492 & 2 & .000 \\
\hline & 6 years and more & 85 & 40 & 0 & & & \\
\hline
\end{tabular}

Source: field survey, 2020

\section{Table 4: Chi-square relationship between hepatitis knowledge level respondents socio-demographic factors}

\section{Respondent's attitude towards hepatitis B prevention}

More than half $(56.1 \%)$ of the respondents were concern about being infected with hepatitis B. Majority $(94.4 \%)$ of the respondents had a positive attitude towards hepatitis B vaccination. Most (87.9\%) of the respondents disagreed that Changing damaged gloves during blood collection is a waste of time. About half $(50.5 \%)$ of the respondents were of the view that all patients should be tested for hepatitis before they are allowed for healthcare and meanwhile, $68.2 \%$ disagreed that they are not comfortable taking care of people infected with hepatitis B. Most $(90.9 \%)$ were willing to test for hepatitis B, 53.0\% had Self-perceived risk of hepatitis B and $85.9 \%$ of them believed following infection control guidelines will protect them from hepatitis B (Table 5).

\begin{tabular}{|l|l|l|l|}
\hline \multicolumn{2}{|l|}{} & Frequency (n =198) & Percentage \\
\hline \multirow{3}{*}{ I have a concern about being infected with HBV } & Agree & 111 & $56.1 \%$ \\
\cline { 2 - 5 } & Neutral & 24 & $12.1 \%$ \\
\cline { 2 - 5 } Hepatitis B vaccine is safe and effective & Disagree & 63 & $31.8 \%$ \\
\hline
\end{tabular}




\begin{tabular}{|c|c|c|c|}
\hline & Disagree & 8 & $4.0 \%$ \\
\hline \multirow{3}{*}{$\begin{array}{l}\text { Changing damaged gloves during blood collection is a } \\
\text { waste of time }\end{array}$} & Agree & 19 & $9.6 \%$ \\
\hline & Neutral & 5 & $2.5 \%$ \\
\hline & Disagree & 174 & $87.9 \%$ \\
\hline \multirow{3}{*}{$\begin{array}{l}\text { All patients should be tested for hepatitis B before they } \\
\text { receive health care }\end{array}$} & Agree & 100 & $50.5 \%$ \\
\hline & Neutral & 23 & $11.6 \%$ \\
\hline & Disagree & 75 & $37.9 \%$ \\
\hline \multirow{3}{*}{$\begin{array}{l}\text { I do not feel comfortable to take care of people infected } \\
\text { with hepatitis B }\end{array}$} & Agree & 48 & $24.2 \%$ \\
\hline & Neutral & 15 & $7.6 \%$ \\
\hline & Disagree & 135 & $68.2 \%$ \\
\hline \multirow{3}{*}{$\begin{array}{l}\text { Following infection control guidelines will protect me from } \\
\text { being infected with hepatitis B at work? }\end{array}$} & Agree & 170 & $85.9 \%$ \\
\hline & Neutral & 12 & $6.1 \%$ \\
\hline & Disagree & 16 & $8.1 \%$ \\
\hline \multirow{3}{*}{ Willing to test for hepatitis B } & Agree & 180 & $90.9 \%$ \\
\hline & Neutral & 5 & $2.5 \%$ \\
\hline & Disagree & 13 & $6.6 \%$ \\
\hline Self-perceived risk of hepatitis B & $\begin{array}{l}\text { Agree } \\
\text { Neutral } \\
\text { Disagree }\end{array}$ & $\begin{array}{l}105 \\
60 \\
33\end{array}$ & $\begin{array}{l}53.0 \% \\
30.3 \% \\
16.7 \%\end{array}$ \\
\hline
\end{tabular}

Source: field survey, 2020

Table 5: Respondents attitude toward hepatitis B prevention

\section{Respondents' hepatitis B hepatitis attitude level}

About $42.9 \%$ had positive attitude toward hepatitis B prevention and $57.1 \%$ had negative attitude. Chi-square analysis showed significant relationship between respondents' attitude level towards hepatitis B and the following factors: marital status $X^{2}(1,198)=11.090, \mathrm{P}=0.001$, residential address $X^{2}(2,198)=11.411, \mathrm{P}=0.003$ and duration of nursing practice $X^{2}(1,198)=4.769, \mathrm{P}=0.029$. However, the remaining factors were not statistically significant $(\mathrm{P}>0.05)$ (Table 6).

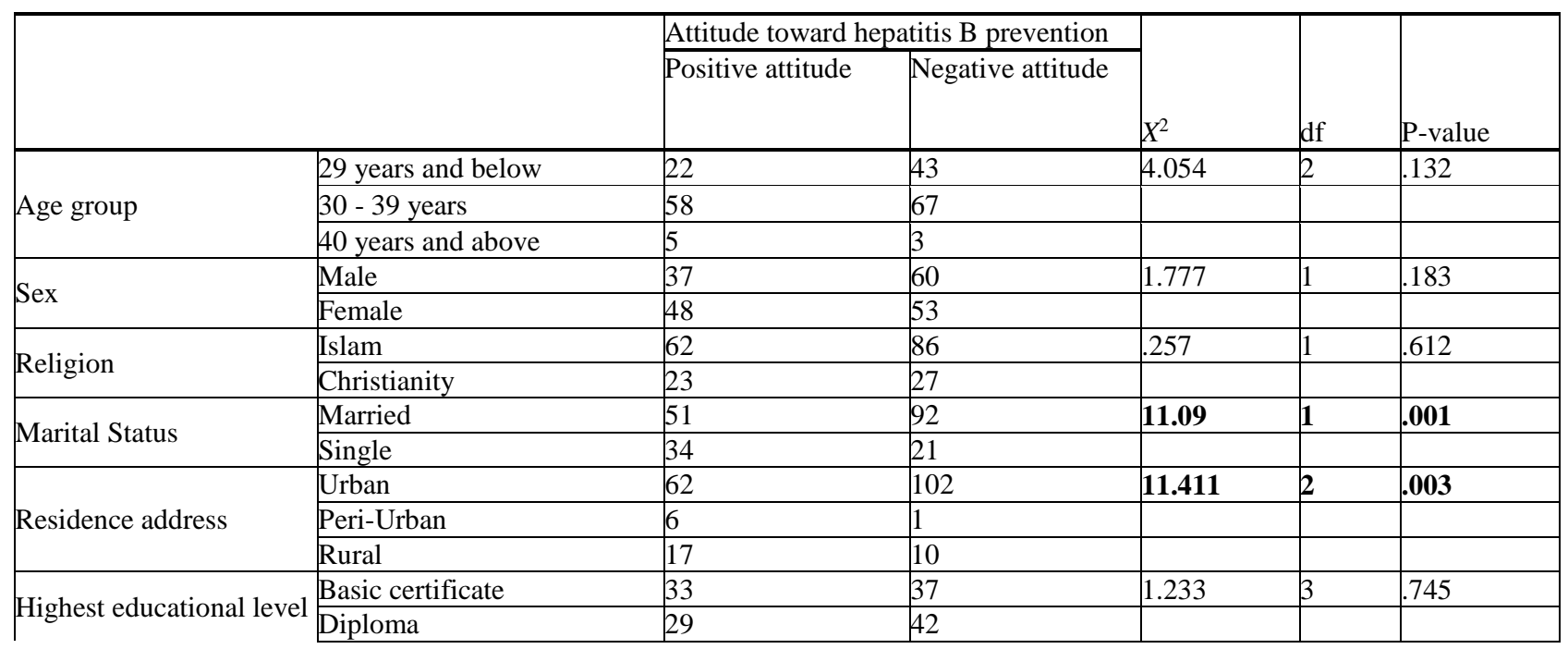




\begin{tabular}{|c|c|c|c|c|c|c|}
\hline & Post diploma & 8 & 9 & & & \\
\hline & Degree & 15 & 25 & & & \\
\hline \multirow{3}{*}{ Nursing category } & Registered general nurse & 27 & 43 & 1.813 & 2 & .404 \\
\hline & Registered midwife & 16 & 25 & & & \\
\hline & Enrolled nurse & 42 & 45 & & & \\
\hline \multirow{2}{*}{\begin{tabular}{|l|}
$\begin{array}{l}\text { Duration of } \\
\text { practice }\end{array}$ \\
\end{tabular}} & 5 years and less & 24 & 49 & 4.769 & 1 & .029 \\
\hline & 6 years and more & 61 & 64 & & & \\
\hline
\end{tabular}

Source: field survey, 2020

Table 6: Chi-square relationship between hepatitis attitude level respondents socio-demographic factors

\section{Respondent hepatitis B vaccination status}

The prevalence of completed (at least three doses) hepatitis B vaccination among the respondents was $77.3 \%$, while $2.5 \%$ had received only one dose of vaccination, $5.1 \%$ had received two doses and $15.2 \%$ had none dose of vaccination. This means $84.8 \%$ (168/198) of nurses started vaccination against hepatitis $B$. It is, however, noteworthy that only $77.3 \%$ of the respondents started completed at least three doses of the vaccination. The only factor with a statistically significant relationship with vaccination completeness status was respondent marital status $X^{2}(1$, $198)=8.063, P=0.005$, vaccination completeness was proportionally higher among those married as compared to those who were single.

\section{Discussion}

The most frequent age in this study was 30 years, which is reflective of the working population in Ghana [11]. The majority of the respondents knew that hepatitis B is caused by a virus and only a few of the respondents indicated that hepatitis B can be caused by bacteria and fungi. The implication of this is that most of the nurses are on point on the causes of hepatitis B because hepatitis B is a viral infection and not caused by bacteria, fungi, or worms [12]. From the literature, the common routes of hepatitis B infection include unprotected sex, mother to child during childbirth, and as well as contact with blood or body fluid of infected person and most of the study respondents knew this [12]. On prevention, the majority indicated that hepatitis $\mathrm{B}$ is preventable by vaccination and just about $56.1 \%$ knew that there was post-prophylaxis medication for hepatitis B. Also, $91.9 \%$ knew that hepatitis B is preventable by Standard precaution practices. According to the world health organization best prevention of hepatitis B is by vaccination and this is safe for all categories of people [12]. There are preventive actions which can be taken by health care workers to prevent and reduce hospital-acquired infections, which include adhering to standard precautions and vaccination against the disease such as hepatitis B [13, 14].

The majority (59.6\%) of the respondents had high knowledge of hepatitis B, 36.4\% had moderate knowledge and $4.0 \%$ had low knowledge of hepatitis B. This study result is good when compared with a study, which revealed only adequate $(67.3 \%)$ knowledge and preventive practices regarding hepatitis B among nurses [7]. This is still a better result when compared with a study discloses that $43.8 \%$ of healthcare workers had poor knowledge [15].

Study analysis showed a statistically significant relationship between the hepatitis knowledge level and the following factor: age, sex, educational level, nursing category, and duration of nursing practice. This result was reinforced in another study conducted in public hospitals in White Nile State; it revealed no affiliation between age, sex, marital status, and hepatitis B knowledge of health care workers [17]. Meanwhile, a study by Hassan et al. indicated that there was no significant relation between good knowledge of Hepatitis infection and socio-demographic characteristics such as age, sex, duration of service, marital status, and religion [16].

More than half of the respondents were concern about being infected with hepatitis B. This is not good because all must be concern about getting infected irrespective of vaccination status, since vaccination is for hepatitis B alone, and there are other related infectious diseases. According to the Ministry of Health Ghana (MOH), gloves are to be changed immediately when damage during procedures and proper hand hygiene performed and this was the view of most of the respondents [14].

About $42.9 \%$ had a positive attitude toward hepatitis B prevention and $57.1 \%$ had a negative attitude. This study finding is very low when compared with a similar study which reported that a great majority of the respondents $(86.4 \%)$ with a favorable attitude towards the preventive measures of HBV infection [18]. Also, a study in Bantama Ghana revealed that out of the 175 respondents, $2.28-25.13 \%$ were within the negative attitude range while $69.14-91.9 \%$ presented a positive attitude towards HBV however 4.57-5.7\% were unaware of the issues [19].

This current study showed a significant relationship between respondents' attitude level towards hepatitis B and the following factors: marital status, residential address, and duration of nursing practice. In Mursy and Mohamed's study, there was no significant relationship between attitude level and socio-demographic factors such as duration of work, age, etc [18]. Also, a study result in Ghana revealed no significant relationship between attitude and respondents' demographic characteristics [19].

Hepatitis B vaccine is $95 \%$ effective in preventing HBV infection and its chronic consequences [12]. The prevalence of completed (at least three doses) hepatitis B vaccination among the respondents was $77.3 \%$, while $2.5 \%$ had received only one dose of vaccination, $5.1 \%$ had received two doses and $15.2 \%$ had none dose of vaccination. This means $84.8 \%$ $(168 / 198)$ of nurses started vaccination against hepatitis B. It is, however, noteworthy that only $77.3 \%$ of the respondents started and completed three doses of the vaccination. This study finding is better as compared to several studies worldwide which indicated low hepatitis B vaccination coverage among health care workers [7, 17, 20, 21, 22]. In a Ghana study, $66.8 \%$ of respondents have been vaccinated and $49.4 \%$ of those vaccinated stated the vaccination concluded the full dose of the vaccination [21].

The study revealed a statistically significant relationship between vaccination completeness status and respondent marital status. Vaccination completeness was proportionally higher among those married as compared to those who were single. In a similar study marital status determines the vaccination status of HCWs [23].

This study is not without limitation as all factors related to hepatitis B vaccination compliance were not all explored.

\section{Conclusion}

The nurses' knowledge level on hepatitis B was very good but less than half the nurses had a positive attitude towards hepatitis B prevention. In terms of vaccination more than three-fourth of them started and completed three doses of hepatitis B vaccination. Good knowledge is not enough for first against hepatitis B infection in our health facilities and our communities. This study highlights the urgent need to improve HBV infection and approaches that warrant that nurses and other healthcare workers are screened and fully vaccinated against the infection to prevent potential future exposure to the virus. 


\section{References}

1. WHO. GLOBAL HEPATITIS REPORT, 2017. Department of HIV/AIDS. Geneva: Global Hepatitis Programme. 2017.

2. Zampino, R, Boemio, A, Sagnelli, C, Alessio, L, Adinolfi, L. E, Sagnelli, E, et al. (2015) Hepatitis B virus burden in developing countries. World J Gastroenterol. 21: 1941-11953.

3. Ofori-Asenso, R, \& Agyeman, A. A. (2016) Hepatitis B in Ghana: a systematic review \& meta-analysis. BMC. 16: 1-15.

4. Spearman, C. W, Afihene, M, Ally, R, Apica, B, Awuku, Y, Cunha, L, et al. (2017) Hepatitis B in sub-Saharan Africa: strategies to achieve the 2030 elimination targets. The Lancet, 900-909.

5. Hepatitis Foundation of Ghana. (2019) Hepatitis: A Ghana situation review. IAPO, 2017.

6. Hussain, S. F, Ahmad, S. R., Muslehuddin, O. M, \& Muslehuddin, H. M. (2016) Knowledge, attitude, and practice regarding hepatitis B among medical students. Int J Community Med Public Health, 3: 977-2981.

7. Mehriban, N, Ahsan, G, \& Islam, T. (2014) Knowledge and preventive practices regarding Hepatitis B among nurses in some selected hospitals of Dhaka city, Bangladesh. South East Asia J Public Health, 4: 48-52.

8. Abdela, A, Woldu, B, Haile, K, Mathewos, B, \& Deressa, T. (2016) Assessment of knowledge, attitudes, and practices toward prevention of hepatitis B virus infection among students of medicine and health sciences in Northwest Ethiopia. BMC.

9. Ansa, G. A, Ofori, K. N, Houphouet, E. E, Amoabeng, A. A, Sifa, J. S, Amenuveve, C. K. et al. (2019) Hepatitis B vaccine uptake among healthcare workers in a referral hospital, Accra. Pan Afr Med J. 110 .

10. Ibrahim, C. (2019) PREVALENCE OF HEPATITIS B VIRUS INFECTION AMONG HEALTH CARE WORKERS IN TAMALE TEACHING HOSPITAL. Greater Accra, Ghana: University of Ghana.

11. Ghana Statistical Service, 2010 population, and housing census district analytical report: Tamale Metropolis. (2014) Accra: GSS.

12. World Health Organisation, Hepatitis B. WHO (2019).

13. Chao, J, Chang, E. T, \& So, S. K. (2010) Hepatitis B and liver cancer knowledge and practices among healthcare and public health professionals in China: a cross-sectional study.
14. Ministry of Health Ghana. (2015) National Policy and Guidelines for Infection Prevention and Control in Health Care Settings. Accra: $\mathrm{MOH}$.

15. Mesfin, Y. M., \& Kibret, K. T. (2013) Assessment of knowledge and practice towards hepatitis B among medical and health science students in Haramaya University, Ethiopia. PLoS ONE; 8: 1-6.

16. Hassan, M, Awosan, K. J, Nasir, S, Tunau, K., Burodo, A, Yakubu, A, et al. (2016) Knowledge, risk perception and hepatitis B vaccination status of healthcare workers in Usmanu Danfodiyo University Teaching Hospital, Sokoto, Nigeria. Journal of Public Health and Epidemiology; 53 -59.

17. Ahmed, T, Elsheikh, E, Balla, S. A, Abdalla, A. A, Ahmed, M., Abu, E, \& Bashir, A. A. (2016) Knowledge, Attitude, and Practice of Health Care Workers Regarding Transmission and Prevention of Hepatitis B Virus Infection, White Nile State, Sudan. Am J Public Health; 4: 18-22.

18. Mursy, S. M.-e., \& Mohamed, S. O. (2019) Knowledge, attitude, and practice towards Hepatitis B infection among nurses and midwives in two maternity hospitals in Khartoum, Sudan. BMC Public Health; 19: 1-7.

19. Afihene, M. Y., Duduyemi, B. M., \& Khatib, M. (2015) Knowledge, attitude, and practices concerning Hepatitis B infection, among healthcare workers in Bantama, Ghana: a cross-sectional study. Int J Community Med Public Health; 2: 244-253.

20. Abeje, G., \& Azage, M. (2015) Hepatitis B vaccine knowledge and vaccination status among health care workers of Bahir Dar City Administration, Northwest Ethiopia: a cross-sectional study. BMC Infectious Diseases.

21. Aniaku, J. K, Amedonu, E. K, \& Fusheini, A. (2019) Assessment of Knowledge, Attitude, and Vaccination Status of Hepatitis B among Nursing Training Students in Ho, Ghana. Ann. Glob. Health; 85: 19.

22. Adekanle, O, Ndububa, D. A, Olowookere, S. A, Ijarotimi, O, \& Ijadunola, K. T. (2015) Knowledge of Hepatitis B Virus Infection, Immunization with Hepatitis B Vaccine, Risk Perception, and Challenges to Control Hepatitis among Hospital Workers in a Nigeria tertiary hospital.

23. Ayalew, M. B, \& Horsa, B. A. (2017) Hepatitis B Vaccination Status among Health Care Workers in a Tertiary Hospital in Ethiopia. Hepatitis Research and Treatment. 1-8.
This work is licensed under Creative Commons Attribution 4.0 License

To Submit Your Article Click Here: Submit Manuscript

DOI: $10.31579 / 2693-4779 / 035$
Ready to submit your research? Choose Auctores and benefit from:

*ast, convenient online submission
*igorous peer review by experienced research in your field
*apid publication on acceptance
* authors retain copyrights
* imique DOI for all articles
immediate, unrestricted online access

At Auctores, research is always in progress.

Learn more www.auctoresonline.org/journals/clinical-research-andclinical-trials 